\title{
MENGATASI SULIT KONSENTRASI PADA ANAK USIA DINI
}

\author{
Oleh: AbdulYlim
}

Dosen Jurusan Pendidikan Kepelatihan FIK UNY

\begin{abstract}
Abstrak
Pada prinsipnya berkembang adalah hal yang dinamis dengan berbagai warna perubahan yang terjadi. Namun perubahan yang berjalan dengan dinamis pada kenyataannya harus berhadapan dengan berbagai permasalahan perkembangan yang akan ditemui oleh tiap individu dalam tiap-tiap tahap perkembangan.

Berkaitan dengan itu sangat penting diketahui masalah-masalah yang seringkali terjadi pada anak agar dapat dilkukan preventif atau pencegahan. Minimal jika menghadapi masalah itu, sudah diketahui apa yang semestinya dilakukan dan tidak hanya berdiam diri atau bahkan menimbulkan kepanikan ketika ketidaktahuan. Pada makalah ini akan diuraikan permasalahan tentang kesulitan anak berkonsentrasi. Uraian ini mengenai Apapenyebab anka sulit berkonsentrasi? Gejala-gejala apa yang tampak pada anak? Apa pengaruhnya terhadap perkembangan psikologis dan proses kegiatan belajar anak? Serta intervensi yang bagaimana yang baik untuk menangani permasalahan anak tersebut?
\end{abstract}

Kata Kunci: Sulit Konsentrasi, Anak

Seringkali kita mendengar ada orang tua yang dipanggil oleh pendidik diakibatkan prestasi belajar anaknya tidak mengalami peningkatan atau perilakunya di sekolah yang membuat terganggu teman-temanya. Anak yang demikian seringkali dianggap sebagai pembuat masalah di sekolah. Mereka dianggap nakal, bodoh, dan

MEDIKORA Vol. V, No 1, April 2009: 55-70 
tidak dapat bergaul dengan baik. Salah satu penyebab anak berperilaku seperti itu adalah anak memiliki masalah gangguan pemusatan perhatian.

Gangguan sulit berkonsentrasi atau gangguan pemusatan perhatiahn (GPP) àdalah suatu gangguan pada otak yang mengakibatkan kesulitan konsentrasi dan pemusatan perhatian. Delapan puluh persen anak yang mengalami GPP memperlihatkan kesuliatan belajar dan kelainan perilaku.

Untuk dipertimbangkan sebagai anak yang memiliki gangguandalam pemusatan perhatian atau kesulitan berkonsentrasi, maka gejalanya harus tampak sebelum usia 7 tahun, dan bertahan paling sedikit 6 bulan dan jadi tidak konsisten dalam pertumbuhan seorang anak. Gejala tersebut juga harus bias diobservasi paling sedikit di dua tempat, misalnya di rumah dan di sekolah, dengan bukti kelemahan yang mencolok atau nyata dalam fungsi pekerjaan, akademik atau sosial. Lebih lanjut, gejala tersebut tidak disebabkan oleh gangguan mental, seperti gangguan suasana hati atau kecemasan (Singgih, 2004:87).

Menurut Singgih 2004: 90, ada tiga tipe gangguan pemusatan perhatian, yaitu:

a. Tipe kombinasi. Ini mudah dilihat, sehubungan mereka kurang mampu memperhatikan aktivitas permainan atau tugas, perhatianya mudah pecah dan cenderung mudah kehilangan bukan hanya miliknya yang disukai melainkan buku atau pekerjaan (pr) nya kerap hilang atau tidak lagi diketahui dimana 
ia mehempatkannya. Selain itu juga mudah berubah pendirian, impulsif dan selalu aktif, mereka juga tidak mampu asyik dalam kegiatan yang menghabiskan waktu, seperti mambaca dan bermain puzzle.

b. Tipe predomionan kurang mampu memperhatikan, dianggap sebagai "kadet luar angkasa" dikelas maupun ditempat lain seerti lapangan sepakbola. Mereka kerap kali tidak mendapatkan perhatian oleh para pendidik karena diam dan kecil hati, tetapi bukan berarti mereka "tidak ada". Di kelas mereka tidak memperhatikan pendidik tetapi melihat langitlangai kelas atau bila dilapangan sepak bola atau bermaian di luar kelas, mereka justru mengamati rerumputan bukan bola dan sering tampak melamun. Mereka tidak dapat mengikuti instruksi suatu kegiatan.

c. Tipe predominan hioeraktif-impulsif, cenderung terlalu energik, lari kesana kemari, tidak bisa diam dan melompat seenaknya. Meskipundemikian, mereka kadang membuat heran setiap orang karena mereka sering dapat menaruh perhatian di kelas dan kelihatanya memang belajar, bahkan ketika mereka seakan tidak mendengarkan.

Membicarakan anak yang mengalami gangguan pemusatan perhatian atau sulit berkonsentrasi berkaitan dengan lemah belajar, harus disadari adanya perbedaan besar antara keduanya. Apa yang cenderung biasa dilakukan anak-anak tersebut adalah efek masalah mereka terhadap diri mereka sendiri dan keluarga 
mereka.Ada tiga bidang umum yang meliputi beberapa gejaladari apa yang menandai adanya suatu perbedaan belajar dari anak yang mengalami gangguanpemusatan perhatian atau kesulitan berkons̀entrasi, yaitu:

a) Perkembangan Konsep dan Bahasa

Masalah dalam bidang konsep dan bahsa oleh par profesional disebut "intelegensia linguistik" atau keterampilan bahasa adalah indikator awal dari seorang anak yang beresiko. Kalau bahasa tampak jelas tertunda atau tetap tidak matang sampai waktu yang berkepanjangan, mungkin ini suatu tanda anak mengalami kekurangan mampu memahami, memproses atau mengungkapkan bahasa secara lisan. Tentu saja perkembangan bahasa yang tidak memadai belum tentu menunjukkan adanya perbedaan belajar. Penelitian menunjukkan bahwa meanggapi kebutuhan anak sejak dini, khususnya dibidang bahsa dapat mencegah atau paling sedikit mengurangi masalah sekolah.

b) Keterampilan Persepsi

Perbedaan belajar yang meliputi persepsi, yaitu cara mereka memahami dan memproses informasi yang masuk melalui pancaindra. Seseorang melihat dengan mata, tetapi memproses dan memahami apa yang dilihat dengan pikiran. Titik acuan pertama seorang anak dalam dunia di sekitarnya adalah tubuhnya sendiri. Seorang anak dapat mengucapkan mungucapkan huruf-huruf dan mengenali huruf tertentu ketika melihatnya namun tidak ingat lagi cara menulis huruf tersebut, 
Hal ini meunjukkan bahwa adanya kelemahan dalam mengkoordinasi panca indra dalam menerima dan mengintegrasikan informasi yang diterima.

c) Masalak Perilaku dan Memperhatikan

Seorang anak yang kurang mampu memperhatikan dan berkonsentrasi sangat sulit mengejar pelajaran dengan atau tanpa lemah belajar, meskipun kadang keduanya kerap muncul secara bersamaan. Banyak anak prasekolah tidak bisa diam, terus menurus bergerak dan menggali lingkungan mereka dan tidak dapat bertahan dengan asyik dalam kegiatan yang membutuhkan diam atau berkonsentrasi.

\section{Penyebab Sulit Berkonsentrasi}

Permasalahan gangguan atau pemusatan perhatian yang juga biasa dikenal dengan konsentrasi, diperkirakan berasal dari berbagai faktor, antar lain:

a. Faktor genetik terutama pada anak laki-laki.

b. Gangguan pada masa anak prenatal atau pada masa di dalam kandungan dan pada masa perinatal atau pada saat proses kelahiran.

c. Ibu hamil yang kecanduan alkohol.

d. Akibat trauma kepala, misalnya karena proses proses persalinan yang menggunakan alat bantu.

e. Keracunan timbal, zat pewarna dosis tinggi dalam makanan. 
f. Tekanan psikososial seperti tidak mendapat perhatian dan kasih sayang dari orang tuanya, sehingga kebutuhan dasar anak tidak terpenuhi.

\section{Gejala-Ǵejala yang Tampak}

Menurut Singgih 2004:92, biasanya anak mengalami GPP akan memiliki ciri-ciri sebagai berikut:

a. Gangguan perhatian. Anak tidak mampu memusatkan perhatianya kepada sesuatu hal atau obyek tertentu untuk jangka waktu yang cukup lama.

b. Distraktibilitas. Akibat kekurangna perhatian, anak GPP mempunyai kecenderungan untuk memperhatikan rangsang yang kurang menonjol, yang dapat berupa distraktibilitas visual (peneglihatan) auditoris (pendengaran) dan internal. Pada distraktibilas visual, konsentrasi visual dialihkan kebendabenda yang dilihatnya. Kedua matanya terus menerus menyelidik dan mencari pengalaman visual yang lebih baru serta lebih baik. Akibatnya anak GPP sering memperlihatkan kekeliruan khas sewaktu membaca dan cenderung melompati kata-kata atau bahkan melewati begitu saja kalimatnya.

c. Hiperaktivitas. Hiperaktivitas merupakan aktivitas motorik yang tingi dengan ciri-ciri aktivitas selalu berganti, tidak mempunyai tujuan tertentu, ritmis dan tidak bermanfaat. Anak hiperaktif lebih banyak mengalami gerakan mata diluar tugasnya, sehingga gerakan menoleh lebih banyak dibandingkan anak normal. Gejala tersebut akan berkurang sesuai dengan 
bertàmbahnya umur dan sebagian akan menghilang pada waktu masa remaja.

d. Impulsif. Anak dengan GPP cenderung bertindak tanpa memeptimbangkan akibat tindakan itu. Mereka cenderung memberikan respon pertama yang masuk dalam pikiranya yang lebih senang "cepat selesai" dalam mengerjakn sesuatu dan tidak mngutamakan ketelitian. Akibat impulsivitas: anak GPP tidak tepat dalam membaca, mengeja, dan berhitung meskipun konsep dasarnya telah dikuasai dengan baik.

e. Tidak pernah puas. Biasanya anak GPP akan selalu meminta pada orang tuanya dan bila keinginanya telah terpenuhi anak GPP tidak akan puas begitu saka akan tetapi akan meminta hal lain.

f. Kurang ulet. Anak GPP akan menunjukkan sifat kurang ulet dalam bekerja sehingga pekerjaanya jarang pernah selesai. Anaka GPP juaga akan mudah lelah sehingga bila berfikir lama akan mudah menguap, menggeliat.

g. Selalu berubah. Perhatian anak GPP akan sangat tergantunga pada motivasinya. Padamotivasi yang tinggi fokus pehatian akan lebih tajam, misalnya: mengikuti acara televisi tertentu.

h. Inkoordinasi. Anaka GPP sukar melakukan kegiatan motorik halus, sehingga mengalami berbagai kesuliltasn seperti mengikat tali sepatu, mengancingkan baju.

MEDIKORA Vol. V, No 1, April 2009: 55-70 
Dengan mngetahui penyebab dan gejala-gejalayang tampak pada anak yang mengalami gangguan npemusatan perhatian atau kesulitan dalam berkonsentrasi, akan memberikan pemahaman bahwa 'anak dalam kondisi yang demikian juga mengalami masalah-masalah psikologis. Masalah-masalah yang dialami dapat dibagi mnjadi dua kategori masalah, yaitu masalah yang bersifat primer dan sekunder.

\section{a. Masalah yang Bersifat Primer}

Yaitu masalah yang berhubungan dengan kognisi, seperti perceptual kognitif yang mencakup persepsi penglihatan, pendengaran, visual motorik, daya ingat, kemampuan berfikir seperti susunan berfikir hingga sulit merencanakan, mengorgabisasikan sesuatu, memanipulasi, menggunakan konsepkonsep atau simbol.

\section{b. Masalah yang Bersifat Sekunder}

Ada masalah yang merupakan kelanjutan dari maslah primer yang sering kali menyebabkan seorang anak didiagnosa mengalami gangguan pemusatan perhatian atau kesulitan berkonsentrasi. Diagnosa ini diambil dengan memperhatikan beberapa penyebab yang mungkin mereka alami, sebagai berikut:

1) Kesulitan dalam bidang pendidikan seperti kesulitasn membaca, berhitung atau matematika, menulis dan atau mengingat.

2) Kesulitan dalam berhubungan dengan orang lain. Kesulitan dalam bidang pendidikan menyebabkan anak sering ditegur oleh pihak lingkungan baik rumah maupun sekolah karena 
prestasi yang dicapai anak kurang. Hal ini menyebabkan anak cemas, rendah diri, dan tidak jarang menampilkan perilaku agresif sehingga mnimbulkan kesulitan dalam menjalin hubunglan dengan orang lain.

3) Perkembnagn dalam bicara dan berbahasa, seperti sulit mengekspresikan ide secara sistematis dan jelas. Sulit memecahkan masalah atau persoalan-persoalan secara verbal. Anaka mengalami kesulitan untuk mempertanyakan sesuatau dan sulit membangun komunikasi.

4) Kesulitan dalam penyesuaian dengan lingkungan

5) Permasalahan dalam motorik seperti integrasi sensorik dan motorik, gerakan-gerakan motorik yang kaku atau tidak hentinya bergerak terus menerus.

6) Masalah dalam meregulasi (mengatur) emosi.

7) Toleransi terhadap frustasi rendah.

8) Kesulitan dalam motivasi. Upaya seringkali tidak menetap dan konsisten, tampak dari hasil upayanya yang dapat naik namun juga seringkali dibawah rata-rata atau kurang.

\section{Pengaruh Sulit Berkonsentrasi Terhadap Perkembangan Anak}

Anak dengan masalah ketidakmampuan untuk memusatkan perhatian sangat berpengaruh tidak hanya bagi anak itu sendiri, tetapi juga bagi teman-teman sekelasnya. Karena kurangnya pemusatan perhatian anak sring gagal dalam mengerjakan tugas secara detail atau kesalahan dalam tugas sekolah, pekerjaan atau

MEDIKORA Vol. V, No 1, April 2009: 55-70 
aktivitas lainya. Jika perilaku ini berlanjut, maka ia akan menjadi individu kurang bisa menimba ilmu, mengabaikan tugas, kurang mampumengorganisir aktivitasnya, mudah terganggu stimulus dari luar bahkan menjadi orang yang mudah lupa.

\section{Intervensi}

Hal yang perlu dingat dalammemberikan intervensi anak yang memilki konsentrasi yang rendah haruslah sabar dan jangan memaksa karena anak cenderung memberontak. Cermati keisengan anak, apakah anak senang melaksanakan program kegiatan melalui cerita atau bermain dengan menggunakan alat.

a. Menecermati aktifitas atau kegiatanyang disukainya, dengan ciri anak akan memiliki perhatian yang lebih pada aktivitas tersebut dibandingkan dengan yang lain. Misalnya: anak suka sekali memperhatikan gambar-gambar hewan. Hal ini dapat dijadikan dasar pendekatan kepada anaka melalui hal yang disukainya.

b. Mengajarkan dan menguatkan perhatian yang terfokus dan mendetail. Anak dibimbing bersama untuk memperhatikan sesuatu dengan seksama. Misalnya: dengan memperhatikan stimulus yang berupa gambar-gambar untuk mencari persamaan dan perbedaan. Selain itu bagi anak-anak yang suka bemain balok dan puzzle, dapat bersama-sama mengerjakan. Jenis-jenis mainan educatif seperti itu dapat melatih konsentrasi anak. 
c. Dalarh menata ruang kelas haruslah rapi sehingga anak tidak cepat beralih perhatianunya.

d. Memberi pujian atau ganjaran kepada anak, bila anak berhasil menyele§aikan tugas dengan baik. Perlu diperhatikan bahwa tugas yang diberikan jangan terlalu sulit atau terlalu mudah dan dalam proses menyelesaikan tugas.

Selain intervensi diatas, menurut Rita Eka Izzatty, 2005: 12, intervensi praktis melalui langakh-langkah penanganan bagi anak dengan gangguan perhatian atau sulit berkonsentrasi digambarkan dalam beberapa pendekatan melalui:

\section{1) Mengelola Kelas oleh Pendidik}

a. Memberikan instruksi yang jelas atau komentar yang jelas mengenai ritme suara, mimik dan gerakan yang mengundang perhatian anak tetapi tidak berlebihan

b. Berhenti sejenak untuk memberikan kontrol non-verbal dengan menatap anak yang bermasalah atau mengabaikan tugasnya dengan tidak atau kurang memperhatikan, perlahan mendekati teman sebayanya kemudian mendekatinya dan mengubah posisi sebagai control nonverbal.

c. Mengembalikan fokus pada tugas.

d. Memberikan dorongan dengan penjalasan.

e. Mengecek tugas atau memberikan aturan-aturan dalam nada rendah.

MEDIKORA Vol. V, No 1, April 2009: 55-70 
f. Memberikan pertanyaan tentang perilaku, menanyakan apa yang sedang dilakukan.

g. Diskripsi perilaku untuk mengidentifikasi penyimpangan atau gangguan dengan mendekati anak dan mengarahkanya untk mendeskripsikan periluknya dengan nada rendah.

h. Untuk membangun komunikasi dua arah, diarahkan untuk bisa berbagi.

i. Memberikan pilihan yang dipaksakan, dengan menginstruksikan kebebasan memilih alternatif dengan pengantar kata "atau". Dan konsentrasi pilihan adalah tidak boleh salah pilih.

j. Pengarahan kembali dengan selang waktu atau jeda waktu. Hal ini dilakukan untuk mengantisipasi adanya konfrontasi atau mereda perdebatan.

\section{2). Mengelola Kontingensi Sekolah Rumah}

Manajemen kontingensi sekolah rumah adalah upaya yangdilakukan untuk menangani anak yang sulit berkonsentrasi, penaganan ini dilakukan tidak hanya di sekolah oleh pendidik melainkan saat dia ada dirumah oleh orang tuanya.. Manajemen penanganan dilakukan dengan tetap mengontrol penampilan akademik maupun tingkah laku anak oleh orang tua dan pendidik.

Teknik penanganan ini diupayakan untuk membuat anank dapat mengurangi perilaku mengganggu dikelas serta meningkatkan kinerja terhadap berbagai tugas sekolah, sekaligus dapat digunakan untuk memecahkan masalah di rumah. 
Penanganan ini dianggap sukses karena disesuaikan dengan manajemen kelas. Inti penanganan teknik ini adalah memuji perilaku tepat dan mengabaikan perilku yang tidak tepat (Sutadi, R, K. dan Déliana, S.M, 1996).

\section{3). Pelatihan Kemampuan Sosial}

Pelatihan ini bertujuan untuk meolong anak yang kesulitan dalam memusatkan perhatian dan kesuliitan berkonsentrasi pada saat berinteraksi dengan teman sebayanya. Pelatihan meliputi teknik untuk masuk suatu kelompok, hubungnan timbal balik dengan teman, menyelesaikan konflik dan mengontrol kemarahan.

\section{4). Mengurangi Struktur dan Stimulus}

Anak dengan masalah perhatian mudah sekali perhatiannya berpindah-pindah, maka stimulus yang diberikan pada program kegiatan belajar atau lingkungan kelas yang tidak relevan harus dikurangi. Hal yang diinginkan dari pendidik dalam menyikapi hal ini adalah menaikkan intensitas melalui penggunaan warna-warna cerah pada stimulus yang berhubungan dengan program kegiatan belajar tanpa harus menambah jumlahnya (Ngalim Purwanto, MP, 2000: 42).

Pengurangan stimulus dapat dicapai melalui beberapa modifikasi:
a. Dinding pada langit-langit yang kedap udara
b. Berkarpet
c. Jendela yang tidak tembus pandang
d. Lemari dan rak yang terkunci
e. Pengurangan penggunaan papan yang berwarna

MEDIKORA Vol. V, No 1, April 2009: 55-70 
f. Menggunakan tempat yang berbentuk kubik dan berisi

\section{KESIMPULAN}

Seorang anak yang kurang mampu memperhatikan dan berkonsentrasi sangat sulit mengejar pelajaran, meskipun kadang keduanya kerap muncul secara bersamaan. Anak yang dalam kondisi demikian juga akan mengalami masalah-masalah psikologis.Untuk itu hal yang perlu diperhatikan dalam memberikan intervensi anak yang memiliki konsentrasi rendah haruslah sabar dan jangan memaksa karena anak cenderung memberontak. Dan mencermati anak dengan program kegiatan melalui kegiatan cerita atau bermaian.

Faktor lain yang dapat menurunkan atau mengurangi kemampuan anak untuk mengubah perhatian atau konsentrasi adalah ketika rangsamg lain yang sampai pada dirinya demikian kuat dan sangat sulit untuk dihindari. Salahsatu rangsang yang kuat dan besar pengaruhnya, yang sering mempengaruhi anak dalam banyak keadaan atau situasi adalah rasa sakit. Tanpa adanya keterampilan untuk memusatkan perhatian dengan kuat , maka rasa sakit seperti munculnya nyeri, dapat berpengaruh terhadap penampilan anak.

Kemampuan konsentrasi merupakan suatu keterampilan yang pada hakikatnya dapat dilatih dan ditingkatkan. Konsentrasi sangat mudah terbentuk melalui latihan. Mempertahankan kepekaan psikis dan mengatur energi psikis selama latihan. Hal ini 
tidak saja dapat meningkatkan ketajaman konsentrasi, tetapi juga memperbaiki kemampuan melakukan seleksi terhadap perhatian dan perubahan-perubahan keterampilan.

Bentuk fatihan yang penting sehubungan dengan mengaktifkan proses berfikir atau faktor intelegensi pada umumnya dalah melakukan latihan konsentrasi yang bervariasi. Latihan dapat dilakukan pada tempat-tempat tertentu yang dapat meningkatkan stimulus bagi anak. Semua hal itu tentu membutuhkan penyesuaian yang baru, sebagaimana telah dikemukakan bahwa salah satu faktor dari inteligensi adalah kemampuan untuk menyesuaikan diri terhadap hal-hal baru secara efektif.

\section{Daftar Pustaka}

Johannes Hartoto (2000). Peningkatan dan Perkembangan Anak Melalui Aktivitas Jasmani. Dirjen DIKTI.

Ngalim Purwanto, MP. (2000). Psikologi Pendidikan. Penerbit Remaja Rosdakarya, Jakarta

Niniek Soetini. (2007). Cara Meningkatkan Konsentrasi. Diambil pada tanggal 11 Juni 2008 dari http//surya.co.id/web/index2.php?option=com content\&do pdf.

Rad Marssy (2007). Meningkatkan Daya Ingat Pada Anak. Diambil pada tanggal 23 Februari 2007 dari http://www.mailarchive.com/sukasukamu@yahoogroups .com /msg00537.html.

Rita Eka Izzatty, (2005) Mengenali Permasalahan Perkembangan Anak Usia TK. Depdiknas, Jakarta 2005

MEDIKORA Vol. V, No 1, April 2009: 55-70 
Singgih D Gunarsa, (2004). Psikologi Olahraga Prestasi. Jakarta, Gunung Mulia.

Sutadi, R, K. Deliana, S.M, (1996). Permasalahan Anak Taman Kanak-Kanak. Depdiknas, Dirjen DIKTI 